\title{
Spectral-temporal characterization of wheat cultivars through NDVI obtained by terrestrial sensors
}

\author{
Carlos E. V. Cattani ${ }^{1}$, Murilo R. Garcia ${ }^{1}$, Erivelto Mercante ${ }^{1}$, \\ Jerry A. Johann ${ }^{1}$, Marcus M. Correa ${ }^{2} \&$ Lucas V. Oldoni $^{1}$ \\ ${ }^{1}$ Universidade Estadual do Oeste do Paraná/Centro de Ciências Exatas e Tecnológicas/Programa de Pós-Graduação em Engenharia Agrícola. Cascavel, \\ PR. E-mail: kaducattani@hotmail.com (Corresponding author); murilogarcia7@hotmail.com; erivelto.mercante@unioeste.br; jerry.johann@hotmail.com; \\ lucasoldoni@outlook.com \\ ${ }^{2}$ Universidade Federal Rural de Pernambuco/Departamento de Tecnologia Rural. Recife, PE. E-mail: marcus.metri@gmail.com
}

\section{Key words:}

vegetation index

remote sensing

growth stage

\begin{abstract}
A B S T R A C T
Remote sensing applications in agriculture are presented as a very promising reality, but research is still needed for the correct use of spectral data. The objective of this study was to evaluate the spectral-temporal patterns of eleven wheat cultivars (Triticum aestivum L.). The experiment was conducted in Cascavel, PR, in the year 2014. With the help of the GreenSeeker and FieldSpec 4 terrestrial sensors, spectral signatures were determined and the temporal profiles of the Normalized Difference Vegetation Index (NDVI) were created. Statistical differences between wheat cultivars were analysed using analysis of variance (ANOVA) and Scott-Knott test. Grain yields obtained with INSEY (In-Season Estimate of Yield) factors were correlated. NDVI normalized by degree-days accumulated from the Feekes growth stages 2 and 8 showed to be more consistent in the estimation of grain yield, explaining approximately $70 \%$ of the variation. At the Feekes stage 10.1, wheat cultivars presented different spectral patterns in the near and medium infrared bands. This suggests that these spectral bands can be used to differentiate wheat cultivars.
\end{abstract}

\section{Palavras-chave:}

índice de vegetação sensoriamento remoto estádio fenológico

\section{Caracterização espectro-temporal de cultivares de trigo utilizando NDVI obtido por sensores terrestres}

\begin{abstract}
R E S U M O
Aplicações de sensoriamento remoto na agricultura se apresentam como realidade muito promissora, contudo ainda há necessidade de pesquisas para a correta utilização dos dados espectrais. Objetivou-se, neste estudo, avaliar os padrões espectro-temporais de onze cultivares de trigo (Triticum aestivum L.). O experimento foi conduzido, em Cascavel, PR, no ano de 2014. Com o auxílio dos sensores terrestres GreenSeeker e FieldSpec 4 foram determinadas assinaturas espectrais e criados os perfis temporais do Índice de Vegetação por Diferença Normalizada (NDVI). Verificou-se diferenças estatísticas entre as cultivares de trigo por meio da análise de variância (ANOVA) e do teste de médias de Scott-Knott. Correlacionaram-se as produtividades de grãos obtidas com os fatores INSEY (IN-Season Estimate of Yield). O NDVI normalizado por graus-dias acumulados dos estádios de desenvolvimento Feekes 2 e 8, mostrou-se mais consistente na estimativa da produtividade de grãos, explicando aproximadamente $70 \%$ da variação. No estádio Feekes 10.1, as cultivares de trigo apresentaram padrões espectrais diferentes nas faixas do infravermelho próximo e médio. Isto sugere que essas bandas espectrais podem ser utilizadas para diferenciar as cultivares de trigo.
\end{abstract}




\section{INT RODUCTION}

Remote sensing (RS) has stood out as a technique that allows to monitor agricultural crops along their development cycle (Gao et al., 2017). Vegetation indices are contrasts of the reflectances of the spectral bands, and the normalized difference vegetation index (NDVI) (Rouse Junior et al., 1974) is widely used in agriculture, because of its easy application, allowing a fast and efficient detection of variations in the vegetation (Bernardi et al., 2014).

Studies have already been conducted demonstrating the strong correlation between NDVI and photosynthetically active radiation (PAR) (Gamon et al., 1995), leaf area index (LAI) (Fassnacht et al., 1997), quantity of biomass and nitrogen of the agricultural crops (Hansen \& Schjoerring, 2003). However, for conditions in which there is greater soil cover by plants, NDVI may saturate and become insensitive to alterations in LAI and biomass (Povh et al., 2008). Despite such limitation, efforts have been made to improve the capacity of remote detection of crop yields using NDVI (Mulla, 2013). Raun et al. (1999), in studies on the wheat crop, developed the INSEY (In-Season Estimate of Yield) model, which allows to correlate grain yield with NDVI.

In-situ radiometric measurements may provide detailed data on the spectral characteristics of the targets, allowing to spectrally characterize different objects with no interference of external factors (Martins \& Galo, 2015). Passive sensors detect the solar radiation reflected by the canopy, whereas active sensors emit modulated light by an auxiliary source that will be captured by the sensor, equaling operating under different lighting conditions (Stamatiadis et al., 2010).

In this context, the present study aimed to characterize the spectral-temporal pattern obtained by active and passive terrestrial sensors of eleven wheat cultivars (Triticum aestivum L.), aiming to correlate the spectral pattern of the wheat crop with its grain yield and growth stages, to evaluate the existence of spectral differences between cultivars.

\section{Material ANd Methods}

The experiment was carried out in 2014, in an experimental area of the Research Center of the Agricultural Research Central Cooperative - COODETEC, in the municipality of Cascavel, PR, Brazil ( $\left.24^{\circ} 53^{\prime} \mathrm{S} ; 53^{\circ} 23^{\prime} \mathrm{W} ; 781 \mathrm{~m}\right)$. The climate of the region is classified as mesothermal subtropical (Cfa), according to Köppen's classification and the soil of the experimental area is classified as dystroferric Red Latosol (EMBRAPA, 2006). Plots were installed following the agricultural calendar of the crop for the region, with sowing in May and harvest in September.

The experimental design was in completely randomized blocks with three replicates, using the cultivars as treatments randomly allocated in each block. Plots had dimensions of $5 \times 1 \mathrm{~m}\left(5 \mathrm{~m}^{2}\right)$, with 6 planting rows spaced by $0.17 \mathrm{~m}$. Plots were spaced by 0.5 $\mathrm{m}$ and each block was isolated by 2.5 - $\mathrm{m}$-wide corridors. The following wheat cultivars were evaluated: CD104, CD108, CD116,
CD150, CD154, CD1440, CD1550, BRS Guamirim, BRS Pardela, Mirante and Quartzo, intended for grain production. Sowing was performed using 360 seeds $\mathrm{m}^{-2}$. Fertilization at planting consisted of $330 \mathrm{~kg} \mathrm{ha}^{-1}$ of N, $\mathrm{P}_{2} \mathrm{O}_{5}$ and $\mathrm{K}_{2} \mathrm{O}$, of the concentrated formulation 8-30-20, plus $45 \mathrm{~kg} \mathrm{ha}^{-1}$ of $\mathrm{N}$, in the form of urea, applied broadcast in the wheat tillering stage.

In the beginning of the tillering stage, the herbicide Iodosulfuron-methyl $\left(0.1 \mathrm{~kg}\right.$ of a.i. ha $\left.{ }^{-1}\right)$ was applied to control oats (Avena sp.) and, two weeks later, Metsulfuron-methyl $\left(4 \mathrm{gha}^{-1}\right)$ was applied to control dicotyledons. Pests were controlled using the insecticide Methamidophos, from the chemical group of the organophosphates, at dose of $300 \mathrm{~mL} \mathrm{ha}^{-1}$.

During the crop cycle and through the terrestrial sensors GreenSeeker $^{\mathrm{TM}}$ (NTech Industries Inc., Ukiah, CA, USA) (active) and spectroradiometer FieldSpec 4 (Analytical Spectral Devices, Boulder, CO, USA) (passive), readings were taken at 7-day intervals, and this time interval varied only when the climatic conditions did not allow data collection at field.

For the measurements with GreenSeeker, in each plot, the device was positioned at canopy height of $0.80 \mathrm{~m}$, covering 5 linear meters in approximately 8 seconds, totaling 80 replicates in each plot. With FieldSpec 4, readings were taken between 10 and $12 \mathrm{~h}$. In each block, the device was calibrated using a $\mathrm{BaSO}_{4}$ plate to determine the radiance of a reference Lambertian surface and, immediately after, in each plot and under the same lighting conditions, reading was taken in a previously randomly selected point. For each point, four readings were taken with the sensor positioned $1 \mathrm{~m}$ above crop canopy and its extremity was facing down. Readings were punctual and centered in the plant row. Such arrangement allowed a field of view of approximately 0.40 - $\mathrm{m}$ diameter.

Crop growth stages were identified in all field surveys. Thus, vegetation index values were separated according to the Feekes growth stages (Large, 1954). At the end, plots were harvested and the data were transformed to $\mathrm{kg} \mathrm{ha}^{-1}$, thus obtaining the yield of each plot.

The collected RS data were used to generate temporal profiles of the NDVI (Rouse et al., 1974), for each wheat cultivar. In the statistical analysis, normality was verified by Kolmogorov-Smirnov test and Pearson correlation coefficients (r) were estimated between grain yield and NDVI in different wheat growth stages. After that, analysis of variance (ANOVA) was applied, followed by the Scott-Knott test at 0.05 probability level in the R statistical software, to compare the responses of the NDVI between cultivars and their growth stages.

For grain yield estimation, NDVI data were normalized by the factors DFP INSEY (Eq. 1) and GDD INSEY (Eq. 2), used by Teal et al. (2006), taking into consideration sowing date and cumulative growing degree-days (GDD) (Eq. 3) calculated based on maximum $\left(\mathrm{T}_{\max }\right)$ and minimum $\left(\mathrm{T}_{\text {min }}\right)$ temperatures of each day and on the basal temperature $\left(\mathrm{T}_{\mathrm{b}}\right)$ of $4.4^{\circ} \mathrm{C}$ for wheat.

$$
\begin{aligned}
& \text { DFP INSEY }=\frac{\text { NDVI }}{\text { DFP }} \\
& \text { GDD INSEY }=\frac{\text { NDVI }}{\text { GDD }}
\end{aligned}
$$




$$
\mathrm{GDD}=\sum_{\mathrm{i}=1}^{\mathrm{t}}\left(\frac{\mathrm{T}_{\max (\mathrm{i})}-\mathrm{T}_{\min (\mathrm{i})}}{2}-\mathrm{T}_{\mathrm{b}}\right)
$$

where:

DFP - number of days from planting to the reading date; and,

GDD - cumulative growing degree-days from planting date to reading date.

\section{Results AND Discussion}

The variation in minimum and maximum temperatures and rainfall along the experiment is presented in Figure 1. The results were within the historical average of the region, with rainfall of $923 \mathrm{~mm}$ and mean ten-day temperature of $18^{\circ} \mathrm{C}$. According to Cordeiro et al. (2015) and Farooq et al. (2011), the water demand of the wheat crop is in the interval from 400 to $650 \mathrm{~mm}$ and the optimal mean ten-day temperature between 19 and $24^{\circ} \mathrm{C}$.

The correlations between grain yield and NDVI change according to the wheat growth stage (Table 1). After verifying data normality at $5 \%$ significance, through Pearson linear correlation, higher correlation $(r=0.57)$ was observed in the beginning of the spike production stage, corresponding to the Feekes growth stage 10.1. Similar results were obtained by Wang et al. (2014), who found the same trend regarding the development stages, but with better correlations between NDVI and grain yield, obtaining $r=0.82$ at the Feekes stage 10 .

The lower correlations between NDVI and grain yield can be partially explained by the considerations of Wang et al.

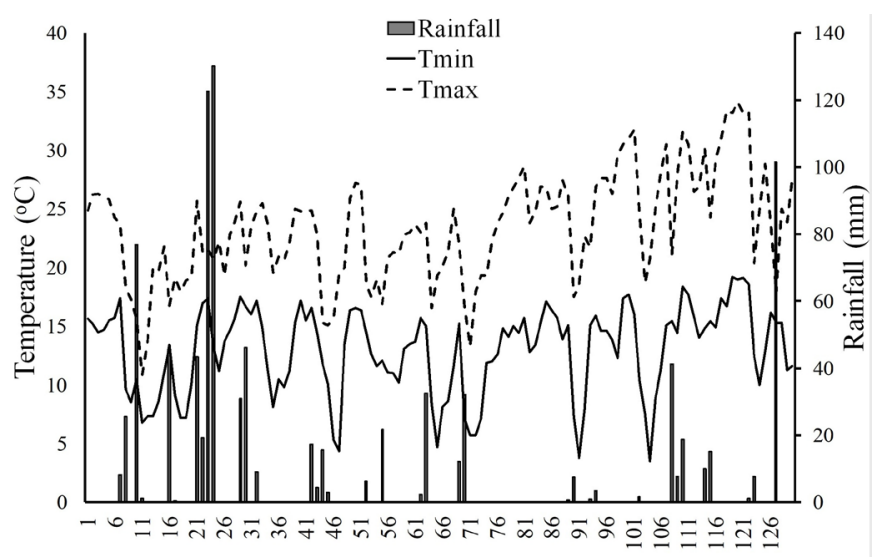

Days after sowing (DAS)

Figure 1. Minimum temperature $\left(\mathrm{T}_{\min }\right)$, maximum temperature $\left(\mathrm{T}_{\max }\right)$ and rainfall along the experiment in the days after sowing (DAS)

Table 1. Pearson correlation coefficient ( $r$ ) between grain yield and spectral index at different wheat growth stages

\begin{tabular}{lccc}
\hline Growth stage & \multicolumn{3}{c}{$\mathbf{R}$} \\
\cline { 2 - 4 } Feekes 2 & NDVI & DFP INSEY & GDD INSEY \\
Feekes 3 & 0.45 & 0.45 & 0.45 \\
Feekes 5 & 0.56 & 0.56 & 0.56 \\
Feekes 8 & 0.40 & 0.49 & 0.48 \\
Feekes 10.1 & 0.52 & 0.62 & 0.67 \\
Feekes 10.5 & 0.57 & 0.25 & 0.26 \\
Feekes 11 & 0.49 & 0.21 & 0.17 \\
Feekes 2 - 8 & 0.46 & 0.36 & 0.35 \\
\hline
\end{tabular}

${ }^{*}$ Correlation values obtained considering the combination of the Feekes stages 2 to 8
(2014). For these authors, a local calibration is necessary to correlate NDVI and yield, because environmental factors such as radiation, temperature, rainfalls and genotypic variations can contribute to the inconsistency. By studying eleven wheat cultivars, genotypical variations were incorporated to the correlation between NDVI and yield, causing its reduction, confirming the necessity of calibration. Yousfi et al. (2016), studying the yield of two wheat varieties, at two growth stages and three doses of fertilizers, found coefficients of correlation between NDVI and grain yield from 0.36 to 0.74 , a range similar to that found in the present study.

Better correlations were found in the attempt to portray wheat yield and NDVI, by normalizing the spectral index by time (DFP INSEY) and degree-days (GDD INSEY), according to Raun et al. (1999). It can be claimed that the improvement of the estimates is related to the intrinsic characteristics of the wheat crop, since the degree-days factor indirectly reflects the metabolic activity of the plant. The results corroborate the claims of Fischer (2011), that wheat cultivars show little or no response to photoperiod and that development processes are mainly controlled by temperature.

It is noted that, considering the normalized NDVI, better correlations occurred in the vegetative growth stages corresponding to the Feekes growth stages 2 to 8 of the wheat crop, and the Feekes growth stage 8 led to more correlated data, compared with other development stages (Table 1).

Good fits between INSEY and grain yield were not observed in the advanced growth stages (Feekes 10.1 to 11). In this same premise, Raun et al. (1999) recommended that Feekes vegetative growth stages 4 and 5 should be used to calculate the INSEY factor for the wheat crop, because in the Feekes stage 10.1 the wheat crop is already in the spike production stage and completely covering soil surface.

On the other hand, multi-temporal RS data can provide more reliable and useful information than the collection on a single date when grain yield estimation is intended. For the determination of INSEY factor considering the period between two or more growth stages, in general, the correlations increased and the highest value was obtained when related to the combination of the Feekes stages 2 to 8, which can explain $70 \%$ of the wheat yield variation (Table 1 ). This approach considers the increment of NDVI $\left(\Delta_{\text {NDVI }}\right)$ and the time $(\Delta t)$ or growing degree-days $\left(\Delta_{\mathrm{GDD}}\right)$ necessary for the passing from Feekes stage 2 to Feekes stage 8. Sharabian et al. (2013) also obtained higher correlations in the estimates of potential grain production for the wheat crop using the combination of vegetative stages (Feekes 4 - 6). Thus, better estimates of yield of agricultural crops by remote sensing can be obtained when a multi-temporal analysis of vegetation indices is performed (Wang et al., 2014).

For comparison between cultivars, the response of NDVI measured by the active sensor (GreenSeeker) and passive sensor (FieldSpec 4) along the wheat growth stages, was evaluated (Table 2 ).

There were significant differences of NDVI values for the cultivars in the growth stages; however, these differences seem to be more related to physical factors than to genetic factors. In the beginning of wheat development, period of tillering 
Table 2. Mean values of Normalized Difference Vegetation Index (NDVI) for the eleven wheat cultivars in the different growth stages collected with the GreenSeeker and FieldSpec 4 sensors

\begin{tabular}{|c|c|c|c|c|c|c|c|c|c|}
\hline \multirow{2}{*}{ Sensor } & \multirow{2}{*}{ Cultivars } & \multicolumn{7}{|c|}{ Growth stages (Feekes) } & \multirow{2}{*}{$\begin{array}{c}\text { Prod. } \\
\left(\mathrm{kg} \mathrm{ha}^{-1}\right)\end{array}$} \\
\hline & & 2 & 3 & 5 & 8 & 10.1 & 10.5 & 11 & \\
\hline \multirow{11}{*}{ GreenSeeker } & CD 104 & $0.30 \mathrm{~b}$ & $0.44 \mathrm{~b}$ & $0.60 \mathrm{a}$ & $0.81 \mathrm{a}$ & $0.81 \mathrm{a}$ & $0.69 \mathrm{a}$ & $0.42 \mathrm{c}$ & 5.468 \\
\hline & CD 108 & $0.30 \mathrm{~b}$ & $0.46 b$ & $0.52 \mathrm{~b}$ & $0.63 \mathrm{a}$ & $0.73 \mathrm{a}$ & $0.65 \mathrm{a}$ & $0.62 \mathrm{a}$ & 5.834 \\
\hline & CD 116 & $0.30 \mathrm{~b}$ & $0.43 \mathrm{~b}$ & $0.52 \mathrm{~b}$ & $0.66 \mathrm{a}$ & $0.73 \mathrm{a}$ & $0.63 \mathrm{a}$ & $0.56 \mathrm{~b}$ & 5.171 \\
\hline & CD 150 & $0.35 \mathrm{a}$ & $0.55 \mathrm{a}$ & $0.68 \mathrm{a}$ & $0.82 \mathrm{a}$ & $0.83 a$ & $0.79 \mathrm{a}$ & $0.73 \mathrm{a}$ & 7.011 \\
\hline & CD 154 & $0.31 \mathrm{~b}$ & $0.46 \mathrm{~b}$ & $0.61 \mathrm{a}$ & $0.75 a$ & $0.81 \mathrm{a}$ & $0.70 \mathrm{a}$ & $0.60 \mathrm{a}$ & 6.026 \\
\hline & CD 1440 & $0.29 \mathrm{~b}$ & $0.42 \mathrm{~b}$ & $0.49 \mathrm{~b}$ & $0.72 \mathrm{a}$ & $0.79 \mathrm{a}$ & $0.72 \mathrm{a}$ & $0.59 \mathrm{a}$ & 5.753 \\
\hline & CD 1550 & $0.28 \mathrm{~b}$ & $0.41 \mathrm{~b}$ & $0.48 \mathrm{~b}$ & $0.75 \mathrm{a}$ & $0.81 \mathrm{a}$ & $0.68 \mathrm{a}$ & $0.52 \mathrm{~b}$ & 5.957 \\
\hline & BRS Guamirim & $0.31 \mathrm{~b}$ & $0.45 b$ & $0.58 \mathrm{a}$ & $0.73 \mathrm{a}$ & $0.82 \mathrm{a}$ & $0.75 \mathrm{a}$ & $0.64 \mathrm{a}$ & 5.634 \\
\hline & BRS Pardela & $0.30 \mathrm{~b}$ & $0.46 \mathrm{~b}$ & $0.59 a$ & $0.78 \mathrm{a}$ & $0.83 a$ & $0.71 \mathrm{a}$ & $0.65 a$ & 6.647 \\
\hline & Mirante & $0.31 \mathrm{~b}$ & $0.45 b$ & $0.54 \mathrm{~b}$ & $0.75 \mathrm{a}$ & $0.81 \mathrm{a}$ & $0.68 \mathrm{a}$ & $0.53 \mathrm{~b}$ & 7.031 \\
\hline & Quartzo & $0.31 \mathrm{~b}$ & $0.43 \mathrm{~b}$ & $0.52 \mathrm{~b}$ & $0.77 \mathrm{a}$ & $0.83 a$ & $0.73 a$ & $0.63 a$ & 6.271 \\
\hline \multirow{11}{*}{ FieldSpec 4} & CD 104 & $0.35 \mathrm{~A}$ & $0.55 \mathrm{~B}$ & $0.67 \mathrm{~B}$ & $0.91 \mathrm{~A}$ & $0.92 \mathrm{~A}$ & $0.86 \mathrm{~A}$ & $0.54 \mathrm{C}$ & 5.468 \\
\hline & CD 108 & $0.41 \mathrm{~A}$ & $0.59 \mathrm{~A}$ & $0.78 \mathrm{~A}$ & $0.87 \mathrm{~A}$ & $0.91 \mathrm{~A}$ & $0.87 \mathrm{~A}$ & $0.85 \mathrm{~A}$ & 5.834 \\
\hline & CD 116 & $0.38 \mathrm{~A}$ & $0.63 \mathrm{~A}$ & $0.66 \mathrm{~B}$ & $0.82 \mathrm{~B}$ & $0.87 \mathrm{~A}$ & $0.82 \mathrm{~A}$ & $0.72 \mathrm{~B}$ & 5.171 \\
\hline & CD 150 & $0.43 \mathrm{~A}$ & $0.64 \mathrm{~A}$ & $0.84 \mathrm{~A}$ & $0.91 \mathrm{~A}$ & $0.93 \mathrm{~A}$ & $0.92 \mathrm{~A}$ & $0.89 \mathrm{~A}$ & 7.011 \\
\hline & CD 154 & $0.34 \mathrm{~A}$ & $0.58 \mathrm{~A}$ & $0.79 \mathrm{~A}$ & $0.88 \mathrm{~A}$ & $0.92 \mathrm{~A}$ & $0.89 \mathrm{~A}$ & $0.76 \mathrm{~B}$ & 6.026 \\
\hline & CD 1440 & $0.31 \mathrm{~A}$ & $0.58 \mathrm{~A}$ & $0.64 \mathrm{~B}$ & $0.88 \mathrm{~A}$ & $0.91 \mathrm{~A}$ & $0.86 \mathrm{~A}$ & $0.77 \mathrm{~B}$ & 5.753 \\
\hline & CD 1550 & $0.31 \mathrm{~A}$ & $0.53 \mathrm{~B}$ & $0.62 \mathrm{~B}$ & $0.90 \mathrm{~A}$ & $0.92 \mathrm{~A}$ & $0.84 \mathrm{~A}$ & $0.74 \mathrm{~B}$ & 5.957 \\
\hline & BRS Guamirim & $0.34 \mathrm{~A}$ & $0.57 \mathrm{~A}$ & $0.67 \mathrm{~B}$ & $0.83 \mathrm{~B}$ & $0.93 \mathrm{~A}$ & $0.91 \mathrm{~A}$ & $0.82 \mathrm{~A}$ & 5.634 \\
\hline & BRS Pardela & $0.32 \mathrm{~A}$ & $0.61 \mathrm{~A}$ & $0.74 \mathrm{~A}$ & $0.90 \mathrm{~A}$ & $0.92 \mathrm{~A}$ & $0.90 \mathrm{~A}$ & $0.83 \mathrm{~A}$ & 6.647 \\
\hline & Mirante & $0.37 \mathrm{~A}$ & $0.54 \mathrm{~B}$ & $0.76 \mathrm{~A}$ & $0.90 \mathrm{~A}$ & $0.93 \mathrm{~A}$ & $0.85 \mathrm{~A}$ & $0.73 \mathrm{~B}$ & 7.031 \\
\hline & Quartzo & $0.33 \mathrm{~A}$ & $0.49 \mathrm{~B}$ & $0.69 \mathrm{~B}$ & $0.90 \mathrm{~A}$ & $0.93 \mathrm{~A}$ & $0.88 \mathrm{~A}$ & $0.83 \mathrm{~A}$ & 6.271 \\
\hline
\end{tabular}

${ }^{1}$ Means followed by the same letter in the column, lowercase (GreenSeeker) and uppercase (FieldSpec 4), do not differ statistically by Scott-Knott test at 0.05 probability level

and stem elongation, which corresponds to the Feekes stages 1 to 10 , NDVI measurements between the cultivars were more distinct. Such distinction can be attributed to the influence of the soil, since in the initial development stages the size of the plants does not allow full soil cover, while most of the area in the plot is not fully covered by the wheat crop. Rissini et al. (2015) also attributed the differences observed in the initial stages of the wheat crop to the influence of the canopy, which may interfere with NDVI levels, because at this moment the crop does not have sufficient biomass to completely cover the soil, and the readings were exposed to both the uncovered soil and the organic matter present in the soil. The statistical differences found at the end of the cycle can be attributed to the different leaf architectures, which vary according to each one of the cultivars.

The results corroborate, therefore, the study of Grohs et al. (2009), in which there were no significant differences of NDVI in the five wheat cultivars. These authors inferred that the difference in the values of reflectance between cultivars in the range of near infrared and red is not sufficiently relevant to indicate their productive potential.

In the spectral signature of the wheat cultivars (Figure 2), obtained in the Feekes stage 10.1, difference was found between the reflectance values in the ranges of near infrared (750-1300 nm) and medium infrared (1450-1800 nm). Similar results were obtained by Thorp et al. (2015), studying cotton cultivars. These authors found higher variability of reflectance in the near infrared $(760-1350 \mathrm{~nm})$ compared with the visible (400-700 nm) and medium infrared (1450-2400 nm).

The results suggest that spectral information of near infrared and medium infrared can be an alternative to differentiate wheat cultivars, such as the NDMI (Normalized Difference Moisture Index) used by Jin \& Sader (2005), to study vegetation.

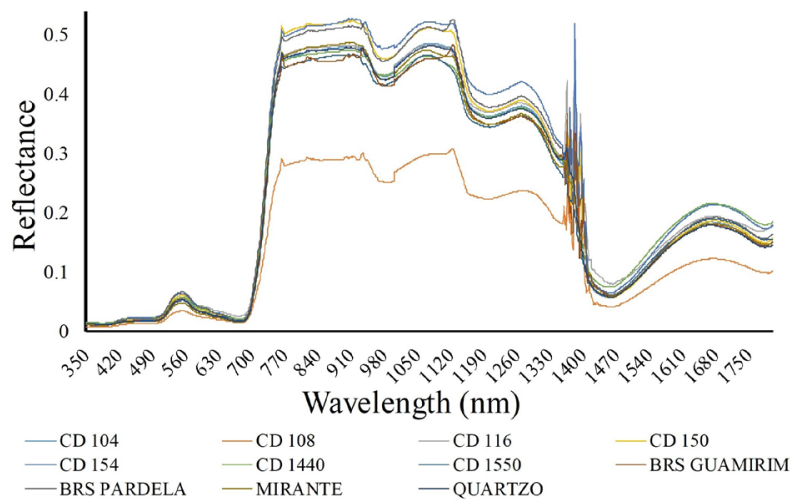

Figure 2. Spectral reflectance of the wheat cultivars at the Feekes growth stage 10.1

\section{Conclusions}

1. Development stage influences the correlation between grain yield and NDVI.

2. The normalized NDVI (GDD INSEY), obtained by reflectance readings at the Feekes growth stages 2 to 8 , showed to be more consistent in the estimation of grain yield, explaining $70 \%$ of the variation in wheat grain yield.

3. With the utilization of RS as auxiliary tool in the selection of genotypes of agricultural crops, phenotypic differentiations between wheat cultivars could not be determined using NDVI.

4. The studied wheat cultivars showed different spectral patterns in the range of near infrared (750-1300 nm) and medium infrared $(1450-1800 \mathrm{~nm})$ in the Feekes growth stage 10.1 , suggesting that these spectral bands can be used to differentiate wheat cultivars.

\section{Acknowledgments}

The authors thank the Coordination for the Improvement of Higher Education Personnel (CAPES), the National Council 
for Scientific and Technological Development (CNPq) and the Araucária Foundation (FA-PR).

\section{Literature Cited}

Bernardi, A. C. de C.; Rabello, L. M.; Inamasu, R. Y.; Grego, C. R.; Andrade, R. G. Variabilidade espacial de parâmetros físicoquímicos do solo e biofísicos de superfície em cultivo do sorgo. Revista Brasileira de Engenharia Agrícola e Ambiental, v.18, p.623-630, 2014. https://doi.org/10.1590/S141543662014000600009

Cordeiro, M. B.; Dallacort, R.; Freitas, P. S. L. de; Seabra Junior, S.; Santi, A.; Fenner, W. Aptidão agroclimática do trigo para regiões de Rondonópolis, São José do Rio Claro, São Vicente e Taguará da Serra, Mato Grosso, Brasil. Revista Agro@mbiente On-line, v.9, p.96-101, 2015.

EMBRAPA - Empresa Brasileira de Pesquisa Agropecuária. Centro Nacional de Pesquisa de Solos. Sistema brasileiro de classificação de solos. Brasília: Embrapa Produção de Informação, 2006. 306p.

Farooq, M.; Bramley, H.; Palta, J. A.; H. M. Siddique, K. H. M. Heat stress in wheat during reproductive and grain-filling phases. Critical Reviews in Plant Sciences, v.30, p.1-17, 2011. https://doi. org/10.1080/07352689.2011.615687

Fassnacht, K. S.; Gower, S. T.; Mackenzie, M. D.; Nordheim, E. V.; Lillesand, T. M. Estimating the leaf area index of North Central Wisconsin forests using the landsat thematic mapper. Remote Sensing of Environment, v.61, p.229-245, 1997. https://doi. org/10.1016/S0034-4257(97)00005-9

Fischer, R. A. Wheat physiology: A review of recent developments. Crop \& Pasture Science, v.62, p.95-114, 2011. https://doi. org/10.1071/CP10344

Gamon, J. A.; Field, C. B.; Goulden, M. L.; Griffin, K. L.; Hartley, A. E.; Joel, G.; Peñuelas, J.; Valentini, R. Relationships between NDVI, canopy structure, and photosynthesis in three Californian vegetation types. Ecological Applications, v.5, p.28-41, 1995. https://doi.org/10.2307/1942049

Gao, F.; Anderson, M. C.; Zhang, X.; Yang, Z.; Alfieri, J. G.; Kustas, W. P.; Mueller, R.; Johnson, D. M.; Prueger, J. H. Toward mapping crop progress at field scales through fusion of Landsat and MODIS imagery. Remote Sensing of Environment, v.188, p.9-25, 2017. https://doi.org/10.1016/j.rse.2016.11.004

Grohs, D. S.; Bredemeier, C.; Mundstock, C. M.; Poletto, N. Modelo para estimativa do potencial produtivo em trigo e cevada por meio do sensor GreenSeeker. Engenharia Agrícola, v.29, p.101112, 2009. https://doi.org/10.1590/S0100-69162009000100011

Hansen, P. M.; Schjoerring, J. K. Reflectance measurement of canopy biomass and nitrogen status in wheat crops using normalized difference vegetation indices and partial least squares regression. Remote Sensing of Environment, v.86, p.542-553, 2003. https:// doi.org/10.1016/S0034-4257(03)00131-7

Jin, S.; Sader, S. A. Comparison of time series tasseled cap wetness and the normalized difference moisture index in detecting forest disturbances. Remote Sensing of Environment, v.94, p.364-372, 2005. https://doi.org/10.1016/j.rse.2004.10.012
Large, E. C. Growth stages in cereals illustration of the Feeks scales. Plant Pathology, v.3, p.128-129, 1954. https://doi. org/10.1111/j.1365-3059.1954.tb00716.x

Martins, D. M.; Galo, M. de L. B. T. Caracterização espectral da cana-de-açúcar infectada por nematoides e Migdolus fryanus por espectrorradiometria de campo. Boletim de Ciências Geodésicas, v.21, p.783-796, 2015. https://doi.org/10.1590/S198221702015000400046

Mulla, D. J. Twenty-five years of remote sensing in precision agriculture: Key advances and remaining knowledge gaps. Biosystems Engineering, v.114, p.358-371, 2013. https://doi. org/10.1016/j.biosystemseng.2012.08.009

Povh, F. P.; Molin, J. P.; Gimenez, L. M.; Pauletti, V.; Molin, R.; Salvi, J. V. Comportamento do NDVI obtido por sensor ótico ativo em cereais. Pesquisa Agropecuária Brasileira, v.43, p.1075-1083, 2008. https://doi.org/10.1590/S0100-204X2008000800018

Raun, W. R.; Johnson, G. V.; Stone, M. L.; Solie, J. B.; Thomason, W. E.; Lukina, E. V. In-Season prediction of yield potential in winter wheat. Better Crops, v.83, p.24-25, 1999.

Rissini, A. L. L.; Kawakami, J.; Genú, A. M. Índice de vegetação por diferença normalizada e produtividade de cultivares de trigo submetidas a doses de nitrogênio. Revista Brasileira de Ciência do Solo, v.39, p.1703-1713, 2015. https://doi. org/10.1590/01000683rbcs20140686

Rouse Junior, J. W.; Haas, R. H.; Schell, J. A.; Deering, D. W.; Harlan, J. C. Monitoring the vernal advancement and retrogradation (greenwave effect) of natural vegetation. Greenbelt, MD, USA: NASA/GSFC, Final Report, n. September 1972, p.1-137, 1974.

Sharabian, V. R.; Noguchi, N.; Han-Ya, I.; Ishi, K. Evaluation of an active remote sensor for monitoring winter wheat growth status. Engineering in Agriculture, Environment and Food, v.6, p.118127, 2013. https://doi.org/10.1016/S1881-8366(13)80021-3

Stamatiadis, S.; Taskos, D.; Tsadila, E.; Christofides, C.; Tsadilas, C.; Schepers, J. S. Comparison of passive and active canopy sensors for the estimation of vine biomass production. Precision Agriculture, v.11, p.306-315, 2010. https://doi.org/10.1007/s11119-009-9131-3 Teal, R. K.; Tubana, B.; Girma, K.; Freeman, K. W.; Arnall, B. D.; Walsh, O.; Raun, W. R. In-Season prediction of corn grain yield potential using Normalized Difference Vegetation Index. Agronomy Journal, v.98, p.1488-1494, 2006. https://doi.org/10.2134/ agronj2006.0103

Thorp, K. R.; Gore, M. A.; Andrade-Sanchez, P.; Carmo-Silva, A. E.; Welch, S. M.; White, J. W.; French, A. N. Proximal hyperspectral sensing and data analysis approaches for field-based plant phenomics. Computers and Electronics in Agriculture, v. 118, p. 225-236, 2015. https://doi.org/10.1016/j.compag.2015.09.005

Wang, L.; Tian, Y.; Yao, X.; Zhu, Y.; Cao, W. Predicting grain yield and protein content in wheat by fusing multi-sensor and multitemporal remote-sensing images. Field Crops Research, v.164, p.178-188, 2014. https://doi.org/10.1016/j.fcr.2014.05.001

Yousfi, S.; Kellas, N.; Saidi, L.; Benlakehal, Z.; Chaou, L.; Siad, D.; Herda, F.; Karrou, M.; Vergana, O.; Gracia, A.; Araus, J. L.; Serret, M. D. Comparative performance of remote sensing methods in assessing wheat performance under Mediterranean conditions. Agricultural Water Management, v.164, p.137-147, 2016. https:// doi.org/10.1016/j.agwat.2015.09.016 